\title{
The Performance Analysis of Geotextile Materials Used for Irrigation Water and Weed Control in Stone Garden Landscape Design
}

\author{
Handan Çakar ${ }^{1}$, Özlem Akat Saraçoğlu ${ }^{1}$, Cenk Ceyhun Kılıç ${ }^{1}$, Hülya Akat ${ }^{2}$, Önder Yücel ${ }^{1}$ \\ ${ }^{1}$ Ege University, Bayındır Vocational Training School, Bayındır-İzmir, Turkey \\ ${ }^{2}$ Muğla Sıtkı Koçman University, Ortaca Vocational Training School, Ortaca-Muğla, Turkey
}

Corresponding Author: Handan Çakar, handan.cakar@ege.edu.tr

\begin{abstract}
In recent years, the droughts which have been occurring as a result of global warming, indicate that we need to take serious measures regarding water saving. Contributing to the preservation of the ecological equilibrium by creating environmentally conscious projects in landscape design confronts us as a requirement of professional discipline. In this regard, the necessity to gravitate towards uses which can save water instead of wide grass fields becomes obvious. Stone garden designs, which we encounter in this very moment, present an environmentally friendly alternative to aquatic gardens.

It is thought that, alongside saving water with stone garden designs, the geotextile materials used in these designs would prevent the stones sinking into soil as well as preventing the occurrence of weed, hence lessening the usage of chemicals thus generating gains with regards to decreasing soil pollution. Based on this, the performances of the texturally and structurally different geotextile materials chosen as samples were tested at the testing grounds at the Ege University Bayındır Vocational Training School Campus. Recommendations with regards to ecologically conscious stone garden landscape designing have been made in accordance with the gathered findings.
\end{abstract}

ARTICLE HISTORY

Received: 17.12.2018

Accepted: 16.07.2019

\section{KEYWORDS}

Geotextile, technical textiles, stone garden, water use efficiency, weed control

\section{INTRODUCTION}

In the agricultural sector, the climatological conditions which take place from planting to harvest have great consequences on the economic value and the quality of the produce. During the production of agricultural produce, agricultural technical textiles have been begun to be used in order to minimise the effects of adverse natural conditions and protecting, harvesting and the preservation of the products.

Technical textiles, by definition, are based on the uniting quality of bringing together the performance and decorative attributes and the functions of a quickly increasing number of textile products, thus expressed as "Textile material and products made for their technical performances and functional attributes instead of their aesthetic or decorative attributes" [1].

In many applications such as fishing, the packaging of agricultural produce, in the acceleration of the growing processes of plants, the protection of products from UVrays, protecting animals from adverse weather conditions in husbandry, the disinfestation of agricultural areas, in preventing weed growth, erosion and many other applications such as drainage, agricultural technical textiles are used $[1,2]$.

The protection of natural resources such as soil, air and water, which are essential elements of life itself, is a very

To cite this article: Çakar H, Akat Saraçoğlu Ö, Kılıç C.C. Akat H, Yücel Ö. 2019. The performance analysis of geotextile materials used for irrigation water and weed control in stone garden landscape design. Tekstil ve Konfeksiyon 29(3), 237-245. 
important ecological topic. The recent population growth, technological advances, quickly increasing consumption alongside growing industrialism and climate change caused by global warming, cause the quick deterioration and destruction of natural resources [3]. In this vein, the emphasis put on "natural resources not being completely consumed short term and consumed in a manner which would create a balance between humankind and the nature and allowing the future generations to subsist" in the 1987 report by the World Commission On Environment And Development, has caused the subject of environmental sustainability to gain increasing importance [4]. At this juncture, the choice of water-efficient landscape designs over traditional landscape designs which require great water consumption confronts us as an obligation [5-7].

Water, which is amongst natural resources; is a massively important element which affects life directly, causes maximum efficiency between natural resources, which cannot be produced artificially by humankind and has no alternative. In this day, due to the increased water demand connected to technological advancements and climate change connected to global warming continuously lessen the number of clean water sources $[8,9]$.

Corresponding to the increasing population on soil, the fastest consumed resource on soil is water. In order to at least preserve the status quo of this crucial resource, it needs to be used efficiently. The efficient usage of irrigation water may be achieved by using it in the amount the plant being grown requires. With this objective, irrigation can be carried out in a controlled and regulated manner by supplying irrigation water consistent with the requirements of the plant to be irrigated.

The water consumption reaching great heights in large outdoor areas such as parks or gardens require the development of new landscape designs which use the least amount of water possible in these areas. Due to this reason, under the larger concept of Water-Efficient Landscaping using water in an efficient manner has come up under different names [Water-Wise, Water-smart, Low Water] and gave birth to a new concept against traditional landscape design [10].

In present day when the water resources are quickly being diminished, trailing plants need to be chosen instead of large grass facets which require a great amount of water. Moreover, as an alternative to the aesthetic uses of grass, "stone garden" landscaping designs are being talked about. The concept of "stone gardens" which gives ease of maintenance and minimises water consumption plays a great role in creating environmentally conscious projects [11-13].

For the stone gardens which present themselves as an aesthetically valuable and environmentally conscious water saving alternative to be long-lasting, the necessary attention must be paid during the preparation stage of the application.

Failing that, the aesthetic effect produced during the erroneous executions during the application of the stone garden landscape designs will not last long, the stones laid on the ground will sink and the stone gardens will leave their places to a sight completely taken over by weeds.

Aim of this research is to find out the most suitable geotextile materials used in garden designs would prevent the stones sinking into soil as well as preventing the occurrence of weed, hence lessening the usage of chemicals thus generating gains with regards to decreasing soil pollution. Additionally, recommendations have been made to be able to create long lasting and environmentally conscious projects by establishing weed control in stone garden landscape designs and ascertaining the requirements to desired outcome long lasting without maintenance.

\section{MATERIAL AND METHOD}

The research was carried out at the Ege University Bayındır Vocational Training School during the 3-month long summer period of 2018. In the research which is an open field experiment, different geotextile materials were used to prevent the detrimental effects of the practical materials used in landscape designs. Alongside this, stone materials which are popular in the stone garden landscape designs were used. With this objective, 4 different geotextile materials and 4 different stone materials were taken under trial during the examination application. The materials used for this purpose are summarized below.

\subsection{Research Subjects}

Uncovered group (G0): It has formed the examination application subjects in the research. No geotextile material has been used. In this research topic only the topics regarding the soil surfaces on which the stones were laid have been examined.

Covered group (GT): They are research subjects which consist of geotextile materials which have different attributes. All the geotextile materials and stone materials which have been included in the research are shown on Table 1.

The research was carried out with 3 replications according to the experimental design on randomized blocks. The research, which was conducted as an open field pot experiment, used square cut plastic pots sized $25 \times 25 \times 25 \mathrm{~cm}$ with a drainage exit at the bottom. 60 pots were filled with gravels and then local soil silt in texture which has national attributes to establish 15.625 litre root volume. 
Table 1. Some physical properties of geotextile and stone materials used in the research

\begin{tabular}{llll}
\hline Code & Geotextile Materials & Abbreviation & $\mathbf{g} / \mathbf{m}^{\mathbf{2}}$ \\
\hline G1 & Polyethylene layer $(0.30 \mathrm{~mm})$ & PE & 160 \\
G2 & Polypropylene & PP & 78 \\
G3 & \%100 Polyester un-textured surface & PES & 175 \\
G4 & Jute sack & JU & 280 \\
Code & Stone Materials & Colour & Grain Size (cm) \\
S1 & Sand (washed creek sand) & Natural colour & $0,1-0,2$ \\
S2 & Creek Pebble & Grey & $2 * 3$ \\
S3 & Dolomite & White & $1 * 3$ \\
S4 & Volcanic Tuff & Dark shade & $1,2-1,8$ \\
\hline
\end{tabular}

\begin{tabular}{|c|c|c|c|}
\hline Polypropylene & Uncovered & Polyester & Jute \\
\hline Uncovered & Polyester & Jute & Polyethylene \\
\hline Polyester & Jute & Polyethylene & Polypropylene \\
\hline Jute & Polyethylene & Polypropylene & Uncovered \\
\hline Polyethylene & Polypropylene & Uncovered & Polyester \\
\hline Polypropylene & Uncovered & Polyester & Jute \\
\hline Uncovered & Polyester & Jute & Polyethylene \\
\hline Polyester & Jute & Polyethylene & Polypropylene \\
\hline Jute & Polyethylene & Polypropylene & Uncovered \\
\hline Polyethylene & Polypropylene & Uncovered & Polyester \\
\hline Polypropylene & Uncovered & Polyester & Jute \\
\hline Uncovered & Polyester & Jute & Polyethylene \\
\hline Polyester & Jute & Polyethylene & Polypropylene \\
\hline Jute & Polyethylene & Polypropylene & Uncovered \\
\hline Polyethylene & Polypropylene & Uncovered & Polyester \\
\hline
\end{tabular}

Figure 1. Distribution of applications in the study area and experimental design.

As botanical material; small leafed the sedge plant (Cyperus roduntus) which can develop much more than the wide leafed cultivated plants in the Aegean Region, which is hard to combat the adversary effects of, and commonly seen in the region and the common purslane (Portulaca oleracea) which is wide leafed so that the differences may be observed in leaf forms, which stays in vegetation throughout the summer season, were used.
The culture of the examined Cyperus roduntus herbs was obtained by the plantation of the Cyperus roduntus tubers gathered from the land which makes up the experiment area of 5 each in every pot. Also, in order to observe the reaction of seed germination under geotextile material, 43 seeds each from the Portulaca oleracea plant was planted into each pot. Because the seed germination ratio for the Portulaca olerecea is $94 \%$ according to Tulukcu [14], the 
germinated number of Portulaca oleracea is estimated to be 40 for every 43 seed.

Later on, by laying the stone materials on top of the geotextile materials, with for different geotextile materials and 1 control group, the pots were made ready in order to form combinations of the 4 different stone groups.

Drip irrigation system was used during the dispersal of irrigation water to the pot environments and the application of it. With this objective, drip irrigation laterals made of PE pipes with an outside diameter of $16 \mathrm{~mm}$ have been placed on the pots and a dripper with a flow rate of 2.3 litre/hour for each plant was placed on the lateral line. The automation was established by using a pressure regulator on the pump exit, valve, filter and an electro-valve.

The amount of water used for the irrigation of the materials in the experiment field pots was ascertained by the usage of the aforementioned meter. The drained irrigation water which couldn't be held by the geotextile material and the soil was discharged using 1 drainage hole in the middle of the pot, with a diameter of $16 \mathrm{~mm}$. Before the drained water was discharged from the system, it was tested for volume and the electrical conductivity (EC) and $\mathrm{pH}$ measurements were made. The amount of the irrigation water applied to the pot environment was regulated based on the amount of yearly rainfall the Aegean Region receives.

In order to ascertain how much the used geotextile material hampers light, one of the most important competitive factors between plants, the volume of light beneath and above the geotextile was measured using a luxmeter on a regular basis. The temperature of the soil in the pots was also measured on a regular basis using a pot type digital thermometer. External temperature measurements were also made during the research in order to gather meteorological data for the duration of the research.

The findings gathered at the end of the experiment were entered to the digital environment using the Microsoft Office 2010 Excel programme. Later on using this data, the necessary statistical analyses such as the Kruskal Wallis Test and Mann-Whitney U Test were carried out on the SPSS programme and the data gathered after the analyses were interpreted.

\section{RESULTS AND DISCUSSION}

The research findings were given out in 3 different groups, labelled as "Per the type of geotextile material", "Per the type of stone material" and "Per the condition of having geotextile material".

- The evaluation carried out per the type of the geotextile material was carried out by having the same common stones on the geotextile material for every group.

- The evaluation carried out per the type of stone material was carried out by having the same common geotextile materials underneath for every group.
- The evaluation carried out per the condition of having geotextile material was carried out by comparing the pots which contain geotextile material (the geotextile material is the same for all the groups) to the ones which do not.

Per the type of geotextile material;

Per the type of the geotextile materials used in the research, when they were viewed in terms of permeability, while polyethylene shows no drainage at all, the highest amount of drainage has been detected with polypropylene. The group which contained no geotextile material on demonstrated less drainage than the drainage in polypropylene (Table 2).

When the $\mathrm{EC}$ and $\mathrm{pH}$ values obtained from the drainage water were observed, no significant statistical difference has been found between the groups.

While the soil temperature was found to be the highest in the group which contains no geotextile material, it has been found out to be the least in the group which contains polyethylene. Polypropylene group was found out to have the highest soil temperature in the groups which contain geotextile materials (Table 3).

While light transmittance was found to be at its highest level in the group which contains no geotextile material, it was recorded to be the least in the Jute group. Polyethylene was recorded to be the highest light transmitting geotextile containing group (Table 4).

In the evaluation made to ascertain the weed prevention performance; while the weed growth has the largest ratio in the group which has no geotextile material, polyethylene and polyester were observed to give the same result for both Cyperus roduntus and Portulaca olerecea and both materials did not allow any weed to grow. Polypropylene showed similar results to polyethylene and polyester when it comes to Cyperus roduntus. Jute, on the other hand, was more successful in terms of curtailing Portulaca olerecea while showing very low levels of performance against Cyperus roduntus (Table 5).

Per type of stone materials;

When the permeability, $\mathrm{pH}$ and weed prevention performance of the stone materials used in the research were compared, the groups showed no statistical difference.

While the highest levels of EC were observed in sand, the lowest were observed in volcanic tuff (Table 6).

The highest levels of soil temperature were observed with sand while the lowest were observed with dolomite (Table 7).

The highest values pertaining to light transmittance were observed with dolomite while the lowest were observed with sand (Table 8). 
Table 2. The level of drainage per the type of geotextile materials

\begin{tabular}{|c|c|c|c|c|c|c|c|c|c|}
\hline Variable & Cover type & Qty. & Mean & Minimum & Maximum & Mean Rank & Km. Sq. & $\begin{array}{l}\text { Degree of } \\
\text { Freedom }\end{array}$ & $P$ value \\
\hline \multirow{5}{*}{$\begin{array}{c}\text { Drainage } \\
(\mathrm{ml})\end{array}$} & G0 & 12 & 578.17 & 170 & 930 & 29.75 & \multirow{5}{*}{$36.67 * * *$} & \multirow{5}{*}{4} & \multirow{5}{*}{0} \\
\hline & G1 & 12 & 0.00 & 0 & 0 & 7.5 & & & \\
\hline & $\mathrm{G} 2$ & 12 & 967.70 & 617 & 1225 & 50 & & & \\
\hline & G3 & 12 & 723.76 & 507.5 & 966.67 & 33.46 & & & \\
\hline & G4 & 12 & 607.86 & 0 & 1040 & 31.79 & & & \\
\hline
\end{tabular}

*** significance level $\quad \alpha<0.01$; ** significance level $\quad \alpha<0.05$; * significance level $\quad \alpha<0.1$

Table 3. The soil temperatures per the type of geotextile materials

\begin{tabular}{|c|c|c|c|c|c|c|c|c|c|}
\hline Variable & Cover type & Qty. & Mean & Minimum & Maximum & $\begin{array}{l}\text { Mean } \\
\text { Rank }\end{array}$ & Km. Sq. & $\begin{array}{l}\text { Degree of } \\
\text { Freedom }\end{array}$ & P Value \\
\hline \multirow{5}{*}{$\begin{array}{l}\text { Temperature } \\
\left({ }^{\circ} \mathrm{C}\right)\end{array}$} & G0 & 12 & 27.75 & 25.37 & 29.78 & 39.46 & \multirow{5}{*}{$9.427^{*}$} & \multirow{5}{*}{4} & \multirow{5}{*}{0,051} \\
\hline & G1 & 12 & 26.64 & 25.6 & 28.32 & 20.96 & & & \\
\hline & G2 & 12 & 27.68 & 26.43 & 29.78 & 36.96 & & & \\
\hline & G3 & 12 & 27.21 & 25.32 & 29.78 & 29.71 & & & \\
\hline & G4 & 12 & 26.87 & 25.65 & 29.83 & 25.42 & & & \\
\hline
\end{tabular}

$* * *$ significance level $\alpha<0.01 ; * *$ significance level $\alpha<0.05 ; *$ significance level $\alpha<0.1$

Table 4. The light transmittance levels of the geotextile materials per type

\begin{tabular}{|c|c|c|c|c|c|c|c|c|c|}
\hline Variable & Cover type & Qty. & Mean & Minimum & Maximum & Mean Rank & Km. Sq. & $\begin{array}{l}\text { Degree of } \\
\text { Freedom }\end{array}$ & P Value \\
\hline \multirow{5}{*}{$\begin{array}{l}\text { Light } \\
\text { (lux) }\end{array}$} & G0 & 12 & 13.68 & 1 & 34 & 42.33 & \multirow{5}{*}{$12.415^{* *}$} & \multirow{5}{*}{4} & \multirow{5}{*}{0,015} \\
\hline & G1 & 12 & 6.43 & 1 & 16.5 & 35.46 & & & \\
\hline & G2 & 12 & 3.26 & 1 & 10.17 & 30.54 & & & \\
\hline & G3 & 12 & 1.93 & 1 & 5.33 & 22.58 & & & \\
\hline & G4 & 12 & 1.71 & 1 & 4 & 21.58 & & & \\
\hline
\end{tabular}

*** significance level $\alpha<0.01$; ** significance level $\alpha<0.05$; $*$ significance level $\alpha<0.1$

Table 5. The amount of weed growth per type of geotextile material

\begin{tabular}{lcccccccc}
\hline Variable & Cover type & Qty. & Mean & Minimum & Maximum & Mean Rank & Km. Sq. & $\begin{array}{l}\text { Degree } \\
\text { Freedom }\end{array}$ \\
\hline \multirow{2}{*}{$\begin{array}{l}\text { Cyperus } \\
\text { roduntus }\end{array}$} & G0 & 12 & 11.17 & 5 & 20 & 54.04 & & \\
(number) & G1 & 12 & 0.00 & 0 & 0 & 21 & & \\
& G3 & 12 & 0.17 & 0 & 2 & 22.83 & $46.417 * * *$ & 4 \\
& G4 & 12 & 2.17 & 0 & 8 & 33.63 & & \\
& G0 & 12 & 10.92 & 0 & 23 & 52.33 & & \\
Portulaca & G1 & 12 & 0.00 & 0 & 0 & 23 & & \\
oleracea & G2 & 12 & 0.25 & 0 & 1 & 29.13 & $42.276^{* * *}$ & \\
(number) & G3 & 12 & 0.00 & 0 & 0 & 23 & & \\
\hline
\end{tabular}

*** significance level $\alpha<0.01$; ** significance level $\quad \alpha<0.05$; * significance level $\quad \alpha<0.1$ 
Table 6. EC values per type of stone material

\begin{tabular}{ccccccccc}
\hline Variable & $\begin{array}{c}\text { Stone } \\
\text { group }\end{array}$ & Qty. & Mean & Minimum & Maximum & Mean Rank & Km. Sq. & $\begin{array}{c}\text { Degree of } \\
\text { Freedom }\end{array}$ \\
\hline & S1 & 11 & 791.65 & 613 & 997.67 & 36.82 & & \\
P value
\end{tabular}

$* * *$ significance level $\alpha<0.01 ; *$ significance level $\alpha<0.1$

Table 7. Soil temperatures per stone material type

\begin{tabular}{ccccccccc}
\hline Variable & $\begin{array}{c}\text { Stone } \\
\text { Group }\end{array}$ & Qty. & Mean & Minimum & Maximum & $\begin{array}{c}\text { Mean } \\
\text { Rank }\end{array}$ & Km. Sq. & $\begin{array}{c}\text { Degree of } \\
\text { Freedom }\end{array}$ P value \\
\hline & S1 & 15 & 27.80 & 25.72 & 29.83 & 38.8 & & \\
Temperature & S2 & 15 & 27.21 & 26.08 & 29.2 & 32.03 & $18.938^{* * *}$ & 3 \\
$\left({ }^{\circ}\right.$ C) & S3 & 15 & 26.21 & 25.32 & 27.63 & 14.07 & & 0 \\
& S4 & 15 & 27.70 & 26.23 & 29.78 & 37.1 & & \\
\hline
\end{tabular}

*** significance level $\alpha<0.01 ; *$ significance level $\alpha<0.1$

Table 8. The light transmittance levels of stone materials per type

\begin{tabular}{|c|c|c|c|c|c|c|c|c|c|}
\hline Variable & $\begin{array}{l}\text { Stone } \\
\text { group }\end{array}$ & Qty. & Mean & Minimum & Maximum & $\begin{array}{l}\text { Mean } \\
\text { Rank }\end{array}$ & Ki. Sq. & $\begin{array}{l}\text { Degree of } \\
\text { Freedom }\end{array}$ & P Value \\
\hline \multirow{4}{*}{ Light (lux) } & $\mathrm{S} 1$ & 15 & 1.01 & 1 & 1.17 & 10.17 & \multirow{4}{*}{$36.058 * * *$} & \multirow{4}{*}{3} & \multirow{4}{*}{0} \\
\hline & S2 & 15 & 5.80 & 1.17 & 16.5 & 40.17 & & & \\
\hline & $\mathrm{S} 3$ & 15 & 11.00 & 1.33 & 34 & 44.47 & & & \\
\hline & S4 & 15 & 3.80 & 1 & 24.5 & 27.2 & & & \\
\hline
\end{tabular}

$* * *$ significance level $\alpha<0.01 ; *$ significance level $\alpha<0.1$

Per the condition of having geotextile material;

During the research when the permeability, EC and $\mathrm{pH}$ were compared per the condition of having geotextile material, no difference was found between the groups.

It was ascertained that the soil temperatures were higher in the group which had no geotextile material (Table 9).
It was observed that light transmittance is greater in the group which has no geotextile material (Table 10).

When the evaluation was made under the context of curtailing weed growth, the amount was ascertained to be higher in the group which had no geotextile material compared to the group which did (Table 11).

Table 9. Soil temperatures per the condition of having geotextile material

\begin{tabular}{|c|c|c|c|c|c|c|c|c|}
\hline Variable & Cover & Qty. & Mean & Mean Rank & $\begin{array}{l}\text { Mean } \\
\text { Sum }\end{array}$ & $\begin{array}{c}\text { Mann- } \\
\text { Whitney U }\end{array}$ & $Z$ value & $P$ value \\
\hline Temperature & G0 & 12 & 27.75 & 39.46 & 473.5 & \multirow{2}{*}{$180.5^{* *}$} & \multirow{2}{*}{-1.987} & \multirow{2}{*}{0,047} \\
\hline$\left({ }^{0} \mathrm{C}\right)$ & GT & 48 & 27.10 & 28.26 & 1356.5 & & & \\
\hline
\end{tabular}

$* * *$ significance level $\alpha<0.01 ; * *$ significance level $\alpha<0.05$; 
Table 10. Light transmittance levels per the condition of having geotextile material

\begin{tabular}{lcccccccc}
\hline Variable & Cover & Qty. & Mean & Mean Rank & Mean Sum & $\begin{array}{c}\text { Mann- } \\
\text { Whitney U }\end{array}$ & Z value & P value \\
\hline \multirow{2}{*}{ Light (lux) } & G0 & 12 & 13.68 & 42.33 & 508 & $146^{* * *}$ & -2.661 & 0,008 \\
\hline
\end{tabular}

*** significance level $\alpha<0.01 ; * *$ significance level $\alpha<0.05$;

Table 11. The amount of weed growth per the condition of having geotextile material at the end of the evaluation

\begin{tabular}{ccccccccc}
\hline Variable & Cover & Qty. & Mean & Mean Rank & $\begin{array}{c}\text { Mean } \\
\text { Sum }\end{array}$ & $\begin{array}{c}\text { Mann- } \\
\text { Whitney U }\end{array}$ & Z value & P value \\
\hline $\begin{array}{c}\text { Cyperus } \\
\text { roduntus } \\
\text { (number) }\end{array}$ & G0 & 12 & 11.17 & 54.04 & 648.5 & $5,5^{* * *}$ & -6.327 & 0 \\
$\begin{array}{c}\text { Portulaca } \\
\text { oleracea }\end{array}$ & GT & 48 & 0.58 & 24.61 & 1181.5 & & & \\
(number) & GT & 48 & 0.08 & 25.04 & 1202 & $26 * * *$ & -6.37 & 0 \\
\hline
\end{tabular}

*** significance level $\quad \alpha<0.01 ; * *$ significance level $\alpha<0.05$;

The level of weed prevention per the type of stone materials in the group without geotextile materials;

The results stemming from the evaluation which was made per the type of the stone materials placed on geotextile materials is not listed due to the lack of meaningful statistical difference between the groups. This is thought to have been caused by geotextiles underneath which display the character of curbing weed growth. Therefore, a different evaluation was made with means of pots containing merely stone materials and no geotextiles beneath them with 6 evaluations made of 3 loops. The initial weed amount and the amount at the end of the measurement were compared and the ratio of the difference in between was taken into account as the weed growth percentage (Table 12). As a result of the calculations, the increase ratio was spotted to be a positive one with the Cyperus roduntus. With the Portulaca oleracea, it showed no increase and it has shown an actual decrease in the overall amount which has reflected upon the increase value in a negative manner. The total sum which was reflected upon the result has shown that there was a decrease in total weed growth.

As a result of this, when the stone materials were evaluated in terms of their weed growth prevention performances, while the greatest increase for the Cyperus roduntus was spotted with dolomite, the smallest increase was detected with Volcanic tuffs. With the Portulaca oleracea, the greatest increase was seen with dolomite with volcanic tuffs being a close second, while the smallest increase was seen with creek pebble. When the weed types Cyperus roduntus and Portulaca oleracea are collectively taken into account, while the greatest weed prevention performance was seen to be had with Volcanic tuff, the least was seen to be had with the creek pebble in an environment.

Table 12. Wild weed growth ratios in pots containing no geotextile material but merely stone material

\begin{tabular}{cccc}
\hline ENVIRONMENT & $\begin{array}{c}\text { WEED } \\
\text { increase ratio (\%) }\end{array}$ & $\begin{array}{c}\text { Portulaca oleracea } \\
\text { increase ratio (\%) }\end{array}$ & $\begin{array}{c}\text { Collective } \\
\text { increase ratio (\%) }\end{array}$ \\
\hline S1 & 93.40 & $(-) 74.18$ & $(-) 55.56$ \\
S2 & 133.40 & $(-) 54.18$ & $(-) 33.33$ \\
S3 & 213.40 & $(-) 82.50$ & $(-) 49.62$ \\
S4 & 53.40 & $(-) 80.00$ & $(-) 65.18$ \\
\hline
\end{tabular}

*(-) shows the amount of decrease. 


\section{RESULTS AND DISCUSSION}

When the geotextile materials per type were evaluated with regards to their permeability, polyethylene showed no drainage. With its lack of permeability, this material presents a great obstacle with letting rainfall through to the soil. Until water left the environment through vaporisation, the water accumulated on the stone laid on polyethylene and caused moss growth.

With polypropylene showing as a geotextile material even greater permeability than groups which had no geotextile materials, it showed a great degree of success in terms of draining water. The reason for the groups containing no geotextile material showing less permeability is thought to be the weed growth and the usage of the said water by the weeds.

The lowest soil temperature with the geotextile material containing group was spotted to be the polyethylene group. Polypropylene group on the other hand was spotted to be the group with the highest soil temperature. Based on this, it is seen important to choose polypropylene rather than polyethylene with regards to keeping soil temperatures high.

Soil temperature affects all the physical, chemical and biological processes taking place in soil directly [15]. The existence of water in the soil, its movement, vaporization and air capacity, dissolution processes, microbiological activity, root respiration and plant activity all being influenced by the soil temperature was stated by Tonkaz et al., [16] and Ekberli and Sarılar [17]. In general, in most climatic environments, biochemical activity increases when temperatures rise. [17-19]. The temperatures at seed depth level were understood to be especially important for germination periods and shoot growth [20].

Temperature first affects the seed germination during the development of plants. In general, it is slower for germination to take place in cold soil. Cold soil also is not suitable for plant roots to develop and for plants to grow [20]. The processes which take place during plant development such as assimilation, respiration, perspiration and photosynthesis are also closely related to temperature. Most of the chemical reactions which take place within a plant and soil are quicker to happen in higher temperature than cold $[17,21]$. In general, with temperatures rising the activities also become quicker. Therefore high temperatures hasten development in most plants. Also, temperatures also exert strong influence over the root development of plants and the dissolubility of the sustenance elements in soil and their digestability by the plants [20].

Jute was seen to be the geotextile material with the lowest light transmittance. Due to this low level of light transmittance, even if weeds grow above the surface, they are expected to die off due to the lack of light. However, even though Jute has a low level of light transmittance, due to its big pored characteristics it allowed a small amount of weeds to grow. Polyester which displayed a similar level of light transmittance showed no weed growth due to its complete lack of pores.

No meaningful difference was detected between the Cyperus roduntus and Portulaca oleracea growth rates. In general, all of the geotextile materials showed high degrees of success in preventing weed growth. In this group, polyester and polyethylene came forward due to their complete lack of weed growth.

Sand particles have a size of $2-0.05 \mathrm{~mm}$. It is formed through the rocks being disintegrated due to various climatic events and its structure is connected to its source rock with little capacity to hold water. Under conditions where organic materials are not plentiful and due to a lack of clay clusters, grains of sand can't bond with each other. While their good permeability prevents accumulation of water in rainy climates, it also causes the loss of plant sustenance materials [22]. As it could be inferred, the washed salts accumulated in the drainage and the highest $\mathrm{EC}$ values were gathered from sand.

Dark surfaces absorb a great amount of radiation while bright surfaces reflect it. Therefore due to its dark shade sand was able to increase soil temperatures more compared to the white coloured dolomite and dolomite had the least measured amount of soil temperature.

The light transmittance factor which is directly related with the germination of weed seeds was observed to be at the highest level in the group which contains dolomite while it was observed to be at the smallest levels in sand. This is thought to be due to the smaller grain sized nature of sand compared to stones. Based on this, the results were similar between dolomite and creek pebble due to their similar particular sizes. Therefore, it could be said that light transmittance grows in parallel with grain size of the rocks.

In the research, per the condition of having geotextile material, it was gathered that soil temperatures and light transmittance were greater in the group which had no geotextile material. This could be explained with the geotextile material obstructing the rays of sun from reaching the soil. Also, when evaluated in the context of weed growth prevention performance, the weed growth was gathered to be far less in the group with geotextile material. As a result of this, it is thought that the geotextile materials are successful at curtailing weed growth. It was in particular observed that the Portulaca oleracea due to its wide leaves had a smaller growth rate compared to the narrow leaved Cyperus rodantus and it was concluded that geotextile materials are more effective at curtailing the growth of the wide leaved plants.

When geotextile materials were not used, while the greatest weed growth was observed with creek pebble the least was observed with volcanic tuff. Amongst the stone materials 
used in this research, it could be said that volcanic tuff are the most successful at curtailing weed growth.

\section{CONCLUSION}

The usage of the geotextile materials occur as an important factor which should be paid attention to in the installation of the stone garden landscape designs which present an environmentally friendly alternative to the aquatic gardens. For the desired effect to be continuously had without maintenance with the stone garden landscape designs, the usage of geotextile materials presents itself as a necessity.

Polyethylene which is the most popular geotextile in the applications in the market, while showing great success in terms of curtailing weed growth, allows no permeability or light transmittance due to its pore-less nature. In landscape designs where landscaping plants are used, its nature which allows no transmission of water and light causes problems

\section{REFERENCES}

1. Özdizdar A. 2004. T İstanbul Ticaret Odası, Teknik Tekstiller Sektör Araştırması s.32.

2. Fung W. 2004. Handbook of Technical Textiles 490-522, TheTextile Institute. England.

3. Saltürk M., 2006, Problem of water in the Middle East and analysis of the problem within the perspective of Turkey, Journal of Security Strategies, Vol:3, 21-38

4. Kaypak Ş. 2011. Küreselleşme sürecinde sürdürülebilir bir kalkinma için sürdürülebilir bir çevre. KMÜ Sosyal ve Ekonomik Araştırmalar Dergisi 13(20), 19-33.

5. Knox GW. 2005. Landscape design for water conservation, University of Florida, IFAS Extension, p:3.

6. Aklanoğlu F. 2007, 18-20 October. Climate change impacts on landscape designaand practices, international conference on climate change and environmental effects (UKİDEK), Konya, Turkey.

7. Ertop G. 2009. Global warming and xeriscape planning, Ankara University, Thesis of Master, p 164, Ankara.

8. Evsahibioğlu NA, Akhüzüm T, Çakmak B. 2010. Su yönetimi, su kullaım stratejileri ve sınırı aşan sular, Türkiye Ziraat Mühendisliği VII. Teknik Kongresi.

9. Bayramoğlu E, Ertek A, Demirel Ö. 2013. Su tasarrufu amaciyla peyzaj mimarlığı uygulamalarında kısıntılı sulama yaklaşımı, İnönü Üniversitesi Sanat ve Tasarım Dergisi 3(7), 45-53.

10. Önder S, Polat AT. 2009, 16-18 Haziran. Yeşil alan uygulamalarinda su tasarrufuna yönelik olarak sukkulent yerörtücü bitki türlerinden yararlanma. 1. Ulusal kuraklik ve çölleşme sempozyumu, 480-485. Konya, Turkey.

11. Lightfoot DR. 1993. The cultural ecology of puebloan pebblemulch gardens, human ecology 21, 115-143

12. Anonymous, 2014. Pebble Garden. Web: http://uniquegarden.in/ pebblegarden.html, erişim 11.06.2018. while the accumulation of water on the textile causes growth of moss on the rocks which creates a bad look. In addition, it is possible to rip the covering material in the part pressed on it and it will be possible to weed out. Polypropylene presented itself as a geotextile material which can by-pass all of these drainage disadvantages, is successful weed-curtailing wise and can maintain soil temperatures at a higher level. Due to its permeability, it can discharge excess water away from the environment thus preventing negative factors and diseases from fostering. Therefore, by extension, it would also lessen usage of chemicals and have a positive effect on the environment. Due to these attributes, in stone garden landscaping designs it is recommended to use polyethylene as the geotextile material of choice. Also, depending on the results of the research, a combination of Polypropylene and Volcanic tuff is recommended for maximum performance in weed control.

13. Anonymous, 2016. Garden Design Ideas With gravels. Architecture and Design. Web: https://www.architecturendesign.net/gardendesign-ideas-with-pebbles/ erişim 11.06.2018

14. Tulukcu E. 2012. Bazı tıbbi bitki tohumlarının çimlenme özelliklerinin tespiti. Tarım bilimleri araştırma dergisi 5(1), 101103.

15. Öztekin T, Öztekin S, Oğuz İ. 2008. Tokat-Kazova koşullarında saatlik torak sıcaklıklarının periyodik sinüs dalga eşitliği ile tahmini, Tarım Bilimleri Araştırma Dergisi 1(1), 55-60.

16. Tonkaz T, Doğan E, Aydemir S. 2007. GAP bölgesi toprak sıcaklıklarının alansal değişimleri ve hava sıcaklığı ile ilişkileri, HR.Ü.Z.F.Dergisi 11(1/2), 55-61.

17. Ekberli İ, Sarılar Y. 2015. Toprak sıcaklığı ve isısal yayınımın belirlenmesi. Anadolu Journal Agriculture Science 30, 74-85.

18. Zibilske LM, Makus DJ. 2009. Black oat cover crop management effects on soil temperature and biological properties on a mollisol in Texas, USA. Geoderma, 149: 379385.

19. Terrence HB, Hugh ALH. 2011. Fine scale variability in soil extracellular enzyme activity is insensitive to rain events and temperature in a mesic system. Pedobiologia 54, 141-146

20. Aksak et al., 1995. Toprak Sıcaklığı. Çukurova Üniversitesi Ziraat Fakültesi Toprak Bölümü Mezuniyet Çalışması. Adana

21. Flerchinger GN, Pierson FB. 1997. Modelling plant canopy effects on variability of soil temperature and water: model calibration and validation. Journal of Arid Environments 35, 641-653

22. Altınbaş Ü, Çengel M, Uysal H, Okur B, Okur N, Kurucu Y, Delibacak S. 2004. Toprak Bilimi. Ege Üniversitesi Ziraat Fakültesi Yayınları No:557, 355. 